\title{
SELECTED PROBLEMS OF RHEOLOGY \\ IN THE CONTEXT OF ROCKS BEHAVIOUR. VARIABILITY OF THE MODULUS OF ELASTICITY AS AN EXAMPLE OF THE INFLUENCE OF TIME AND STRESS FACTORS
}

\section{Krzysztof TOMICZEK ${ }^{1}$}

PhD Eng. Krzysztof Tomiczek, Department of Geomechanics and Underground Building, Faculty of Mining, Safety Engineering and Industrial Automation, Silesian University of Technology, Gliwice, Poland

\section{Summary}

Most of the solutions to the problems of rock mechanics, rock mass mechanics, but also soil mechanics and geotechnics ignore the influence of the time factor. The solutions are here and now, at the moment. Meanwhile, plastic-viscosity properties, when rocks are in a 3D stress state, play more and more importance in the course of time. The deformability variability is of particular importance, as measured by the modulus of elasticity $E$. This chapter analyzes the magnitude of this modulus obtained in uniaxial short-term tests and creep tests of a well-known and described, typical sandstone, at different stress values $\sigma_{0}=$ const.

Keywords: rheology, creep of rocks, modulus of elasticity, deformability, viscosity, plastic flow, uniaxial compression test, sandstone

\section{Introduction}

The beginning of rheology dates back to 1928, when on the initiative of Professor Bingham (Lafayette College, Easton, Pa., US) the "Society of Rheology" and the "Journal of Rheology" were established. Rheology has become a branch of physics dealing with the deformation, plasticity and flow of materials (based [19], [20]).

The name "rheology" has been widely used by British scientists since 1930. In 1940 the British Rheologists Club was founded and Scott Blair announced "Introduction to Industrial Rheology."

The reasons for the emergence and development of rheology are to be found in industrial development, which resulted in the production of many new materials. These materials should have specific mechanical properties. Determining the mechanical properties of

\footnotetext{
${ }^{1}$ Krzysztof.Tomiczek@polsl.pl,k.tomiczek@yahoo.co.uk, https://orcid.org/0000-0001-9227-310X Researchgate: Krzysztof_Tomiczek
} 
materials only on the basis of solutions based on the theory of elasticity and viscosity was insufficient. Also, the application of pure plasticity theory turned out to be insufficient. Conferences and symposia on this subject were organized by the American Chemical Society in 1924, 1926 and 1928.

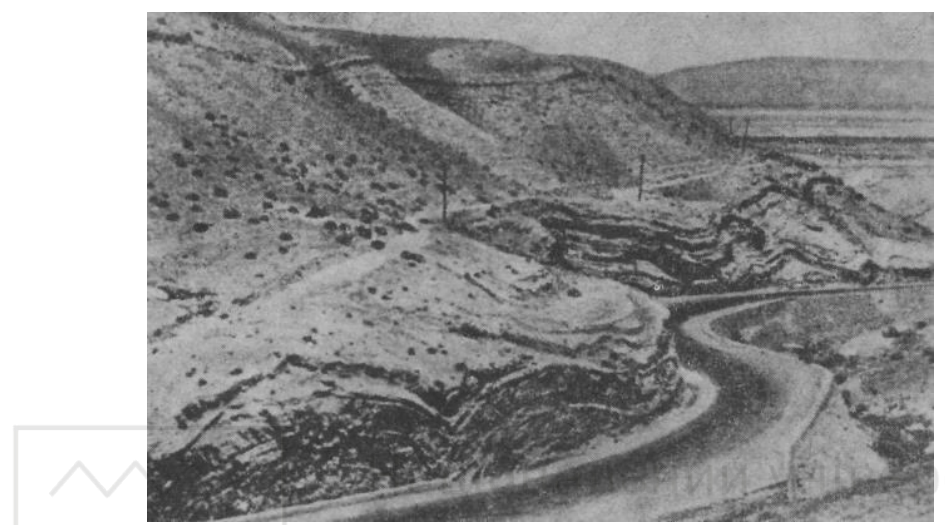

Fig. 1.1. Layers of limestone and flint on the road to Jericho. "Creep in nature is a very long and probably developing process" (Reiner, 1949, 1955)

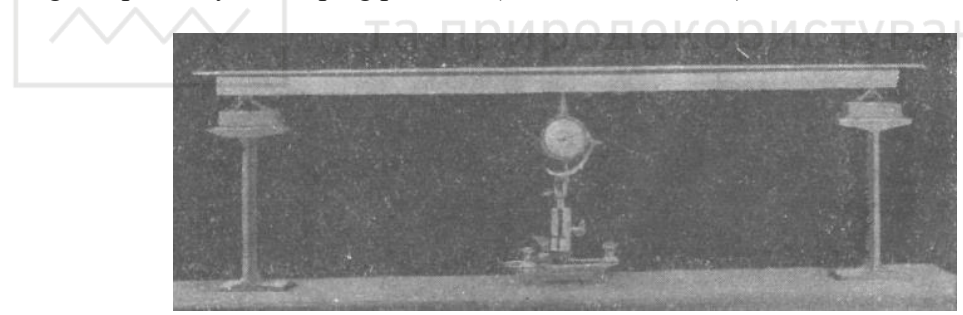

Fig. 1.2. Cement beam at the Tel-Aviv Materials Testing Laboratory showing a permanent increase in deflection from the horizontal line. "The creep phenomenon was observed in the laboratory within one year and is still progressing" (Reiner, 1949, 1955)

Particular attention was paid to the phenomena of plasticity and flow of materials. It was the issues of deformation and flow of materials that became the subject of research by the Society of Rheology and the adoption of the Heraclitus pantha rhei.

Engineers and scientists began to talk seriously about creep, flow, and plasticity as important, and perhaps even the most important, properties of materials. 
The father of rheology is considered to be Marcus Reiner, who from the beginning cooperated with Professor Bingham, and in the years 1931-1934 he gave a series of lectures at Lafayette College and Princeton University.

Reiner in 1937 and 1941 gave a series of lectures at the Hebrew University in Jerusalem. Reiner published, in March 1949 "Twelve lectures on theoretical rheology" (North Holland Publishing Co., Amsterdam), and in 1955 "Rheologie theorique" (Dunod, Paris). At various stages of his work, he cooperated with professors: Bingham, Blair, Hatchekow and Andrad.

\section{Basic concepts}

Rheology is the study of the flow and deformation of materials. Flowing and deformation result from the movement of one body molecule in relation to another (based [9], [26], [27]).

The movement of material bodies is the subject of the field of physics called mechanics.

\subsection{Basic laws of mechanics in rheology}

Theoretical mechanics deals with material points, systems of material points and systems of bodies. In these problems, the properties of the material of the bodies are not analysed, e.g. in solutions to the motion of the planets, planets are treated as material points.

However, the rheological properties of the materials which are made up bodies, such as planets, are different. By analysing the movement of some parts of the body in relation to others, we observe their different behaviour.

Materials can behave differently under the impact of forces. In general, materials under the influence of forces (or load) show the following behaviour:

- elastic; the deformation reaches a certain state under the certain forces (or loads), the state of deformation disappears when we remove the forces;

- plastic, when permanent/ plastic deformations remain after removing forces;

- flow if, under the forces with a constant, limited value the deformations increase indefinitely.

Regardless of the solutions, the rules of mechanics apply in rheology: 
$\underline{1 \text { st principle }}$

where

$$
\Sigma P=a_{0} \cdot m,
$$

$\Sigma$ at $\Sigma P$ - means adding vectors,

$\Sigma P$ - is the resultant of all forces acting on the body,

$m$ - mass,

$a_{0}$ - acceleration of the center of gravity of the body,

wherein the mass $m$ is a scalar.

2nd principle

Let $\Sigma M=\Sigma P_{r}$

where

$r$-force arm, distance from the line of action of the force from the centre of gravity this

$$
\Sigma M=f a \cdot r d m,
$$

where

$f$ - is the integral of all particles, ${ }^{2}$

$a$ - is the acceleration of a molecule with mass $\mathrm{d} m$,

$r$ - now expresses the distance of the acceleration action from the stationary point.

The above equation is also correct if the centre of gravity of the body weight is moving.

3rd principle

Newton's 1st, 2nd and 3rd law (1687) applies:

$\Sigma P=m \cdot a(1$ st and 2nd Newton's law)

$$
A \leftrightarrow B
$$

The action of body A on body $\mathrm{B}$ is equal to the reaction of body $\mathrm{B}$ to A (Newton's 3rd law.

\section{4th principle}

The quantity that characterizes the material of which the body is made is the density $\Sigma$. Density $\Sigma$ is the only one material constant that occurs in mechanics.

$$
\rho=\frac{d m}{d V}
$$

\footnotetext{
${ }^{2}$ it was decided to use the word "particle" rather than "molecule" because of its mass.
} 
where

$m$-body weight,

$d m$ - particle mass,

$V$ - body volume,

$d V$ - volume of the particle.

In rheology, the basic equations relate strain kinematic quantities to stress dynamic quantities using parameters that are constants or material coefficients and that describe the rheological properties of various materials.

\subsection{Basic rheological models of rocks}

According to Kwaśniewski $[13,14]$, the basic functions describing the simple creep process are (Fig. 2.1):

I. Creep equations for linear viscoelastic material with differential models:

Maxwell

$$
\varepsilon(t)=\frac{\sigma_{0}}{E}\left(1+\frac{E}{\lambda} t\right) .
$$

Features of the Maxwell model:

- has the ability to immediate elastic deformation,

- characterized by an inability to elastic after-effect,

- shows only secondary creep properties,

- simple creep describes only the 2 nd stage of the generalized rock creep characteristic.

Features of the Kelvin - Voight model:

- does not have the ability to immediate elastic deformation $\square_{e}=0$,

- characterized by a total elastic retardation,

- shows properties of primary creep only,

- describes only the 1st stage of the generalized creep characteristic.

Zener

$$
\varepsilon(t)=\frac{\sigma_{0}}{E_{1}}+\frac{\sigma_{0}}{E_{2}}\left(1-e^{\frac{E_{2}}{\lambda_{2}} t}\right) .
$$

Features of the Zener model:

- has the ability to immediate elastic deformation $\sqsubset_{e}$, 
- is characterized by a partial elastic after-effect,

- shows properties of primary creep only,

- the standard creep curve describes only the 1st stage of the generalized rock creep characteristic.

\section{Burgers}

$$
\varepsilon(t)=\frac{\sigma_{0}}{E_{1}}+\frac{\sigma_{0}}{E_{2}}\left(1-e^{\frac{E_{2}}{\lambda_{2}} t}\right)+\frac{\sigma_{0}}{\lambda_{3}} t .
$$

Features of the Burgers model:

- has the ability to immediate elastic deformation $\varepsilon_{e}$,

- combines the properties of primary - elastic, and secondary viscous creep,

- describes the 1st and 2nd stage of the generalized creep characteristic.

Where in the equations:

$\sigma_{0}$-constant stress in the creep test,

$t$ - time,

$E, E_{1}$ i $E_{2}$ - longitudinal elasticity coefficients,

$\lambda, \lambda_{1} \mathrm{i} \lambda_{2}$ - longitudinal viscosity coefficients.

II. Creep equations for linear viscoelastic media with integral model:

$\underline{\text { Abel }}$

$$
\varepsilon(t)=\frac{\sigma_{0}}{E}\left(1+\frac{\delta}{1-\alpha} t^{1-\alpha}\right) .
$$

Features of the Abel model:

- has the ability to immediate elastic deformation $\varepsilon_{e}$,

- describes only incompletely the 1 st stage of creep; according to this model, $\varepsilon(\infty)=\infty$. 


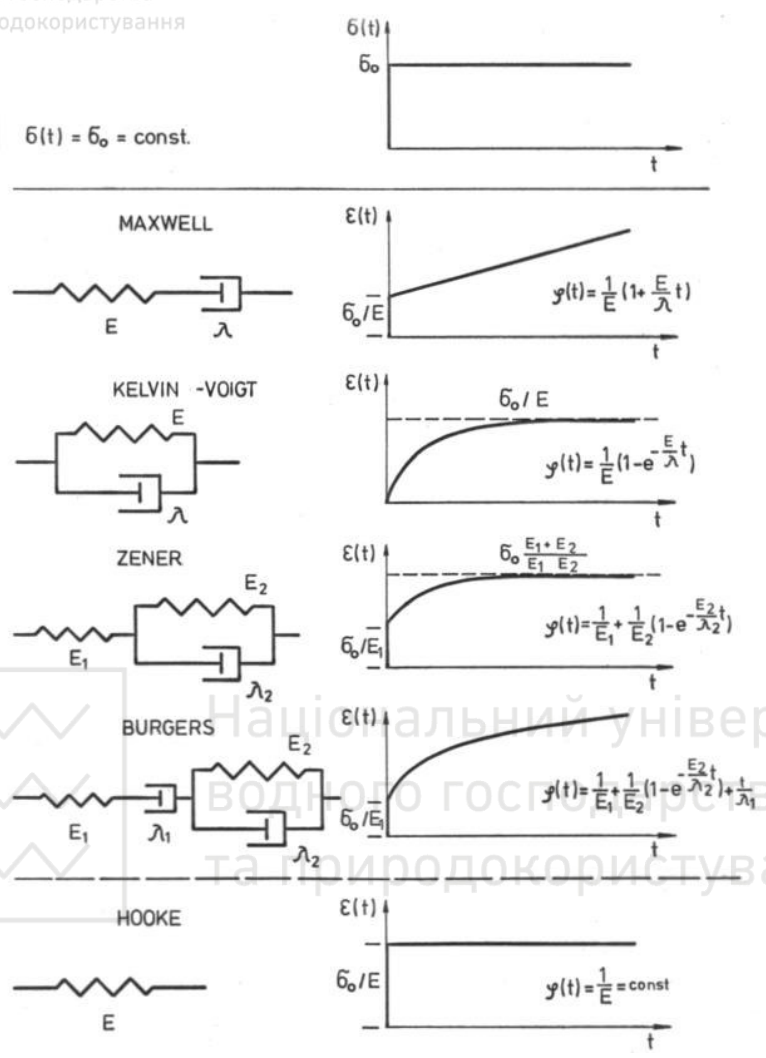

Fig. 2.1. Basic mechanical models and simple creep characteristics of viscoelastic materials after Kwaśniewski (Kwaśniewski, [13])

\section{$\underline{\text { Rabotnov }}$}

$$
\varepsilon(t)=\frac{\sigma_{0}}{E}\left[1+\frac{\chi}{\beta-\chi}\left(1-e^{(\chi-\beta) \tau^{1-\alpha}}\right)\right]
$$

Features of the Rabotnov model:

- has the ability to immediate elastic deformation $\varepsilon_{e}$,

- shows properties of primary creep only,

- describes only the 1st stage of the generalized creep characteristic.

Where in the equations: 
$\delta, \alpha, \chi$ i $\beta$ - creep parameters (Kwaśniewski [13] after Rabotnov[18]).

\section{Carbon rocks creep testing (based on Borecki et al., [1-6])}

\subsection{Basic assumptions}

Research on the creep phenomenon requires the determination of the basic characteristics of the creep process of the rock. These features are:

- limit creep time,

- creep deformations,

- stages of the creep process,

- determination of the simple rock creep function in the air-dry state for various loading levels,

- determination of the linearity or non-linearity of simple creep.

The basic task for describing the creep phenomenon is to determine the creep characteristic, i.e. the relationship $\varepsilon_{i}=f\left(t_{i}\right)$, where $\varepsilon_{i}$ is the deformation (strain) at time $t_{i}$.

The creep curve is the basis for the determination of the creep function and rheological parameters.

The creep test consists of two stages:

I. Increasing the sample load from 0 to the value of stress, at which a specific stress $\sigma_{0}$ induces in the sample cross-section. The stress $\sigma_{0}$ is part of the uniaxial compressive strength $\sigma_{C}\left(\sigma_{0}=(0.4-0.9)\right.$ $\left.\sigma_{C}\right)$. This stress corresponds to the initial deformation $\varepsilon_{0}$.

II. Maintaining a constant load $\sigma_{0}=$ const. (Fig. 3.1) while continuously recording the deformation of the sample taking place in time $\varepsilon=f(t)$.

When testing samples with the method of constant loading, it is assumed that the sample is constantly under the conditions of a constant, unchanging load over time $\sigma=\sigma_{0}=$ const. This assumption is not entirely factual, but admissible (Borecki et al., [5]).

Test conditions [5]:

- accuracy of maintaining a constant load value $\sigma=\sigma_{0}$ : $(0.3-1.0) \%$,

- force measurement: KMBM ring dynamometers, class 0.2 ,

- deformation measurement: a system of 3 dial gauges with an accuracy of $0.001 \mathrm{~mm}$,

- the samples were tested in air-dry conditions. 


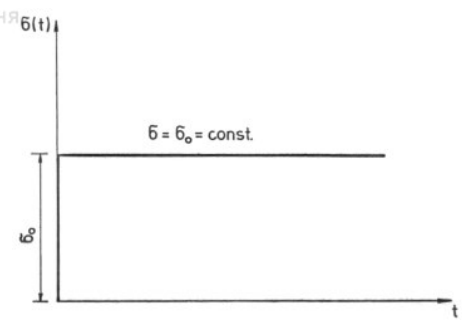

1. $t \rightarrow 0^{+}$

$$
\sigma \rightarrow 0^{+}
$$

$\varepsilon \rightarrow \varepsilon_{0}$

$t=0^{+}$

$\sigma=\sigma_{0}$

$\varepsilon=\varepsilon_{0}$

2. $t>0^{+}$

$\sigma=\sigma_{0}=$ const.

$\varepsilon=f(t)=$ ?

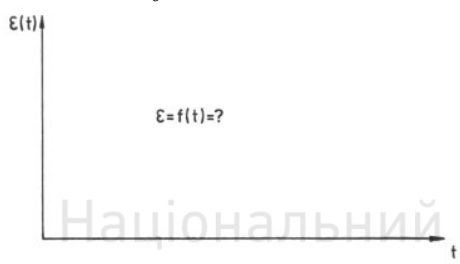

Fig. 3.1. General scheme of the creep test; $\varepsilon$ - strain, $\varepsilon_{0}$ - immediate (initial) strain, $t$ - time, $\sigma$ - stress, $\sigma_{0}$ - initial stress (required, constant, $\sigma==$ const.), lower than $\sigma_{C}$ $\left(\sigma_{0}<\sigma_{C}\right), \sigma_{C}$ - uniaxial compressive strength $[13,5]$

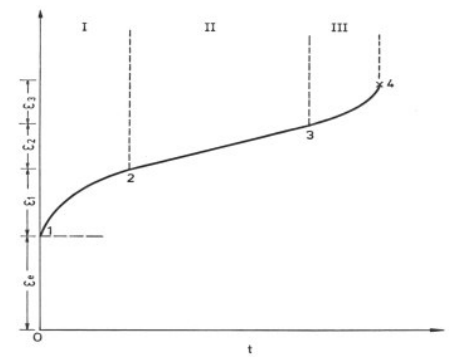

Fig. 3.2. Generalized rock creep curve. I - primary creep, transient, II - secondary creep steady, III - third degree creep, progressive, tertiary; $\varepsilon$ - strain, $\varepsilon_{e}$ - immediate deformation, $\varepsilon_{1}, \varepsilon_{2}, \varepsilon_{3}$-deformations of individual creep stages, $t$-time $[13,5]$.

Figure 3.2 shows a typical, classical rock creep curve under constant stress $\sigma_{0}=$ const. and constant temperature conditions. On its basis, four stages of rock deformation over time can be distinguished:

0 . Elastic deformation occurring at time $t=0^{+}(0-1)$. 
I. First Stage of Creep, primary, transient creep, called elastic creep or elastic flow. The creep speed decreases with time, reaching in point 2 the minimum value for the entire creep process (1-2).

II. Second Stage Creep - secondary, stabilized creep, also called viscous creep, pseudo-viscous flow, or plastic flow. Creep velocity maintains its minimum value from point 2 and remains constant throughout the range (2-3).

III. 3rd Degree Creep - 3rd degree creep, progressive. Short stage. A sharp increase in creep speed causing failure.

The entire rock creep process, and more precisely the total creep deformation:

where:

$$
\varepsilon(\mathrm{t})=\varepsilon_{e}+\varepsilon_{1}(t)+\varepsilon_{2}(t)+\varepsilon_{3}(t)
$$

$\varepsilon_{e}$ - immediate deformation (elastic strain),

$\varepsilon_{1}(t)$ - primary creep strain,

$\varepsilon_{2}(t)=v^{\prime} t$ - secondary creep deformation, where $v=\varepsilon_{2}^{\prime}=$ const is the secondary creep velocity,

$\varepsilon_{3}(t)$ - third degree creep strain,

$t$ - time.

In the case of rock mechanics and rock mass, as well as underground construction, the first and second stages are particularly important, as they influence to the values of deformation pressure on the support of tunnels, chambers, underground heading, including shafts.

\subsection{Apparatus}

The laboratories of the Department of Geomechanics and Underground Construction are equipped with 8 PSH-400 springhydraulic creepers (Fig. 3.3-3.7). Creepers have a simple and reliable design. They enable loading $P_{\max }=480 \mathrm{kN}$ and testing of hard rocks. Loading is carried out by means of 16 hydraulically tensioned steel springs; 2-3 rock samples can be tested in each creeper. 


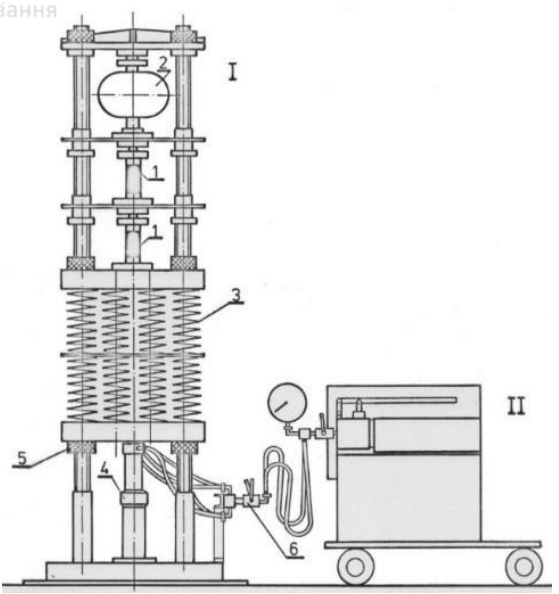

Fig. 3.3. Scheme of the PSH-400 (I) spring-hydraulic creeper with a hydraulic supply (II): 1 - rock samples $(h: d=2) ; 2$ - proving ring for measuring sample loads;

3 - set of $2 \times 16$ springs keeping constant load on the samples; 4 - hydraulic actuators tensioning the set of springs (3) and applying the preload to the samples, then keeps by the springs; 5 - four stop nuts disconnecting the set of springs (3) from the hydraulic actuator system after applying the load to the samples (stress $s=\sigma_{0}$ );

6 - valves shutting off the actuators (4) from the hydraulic supply (II)

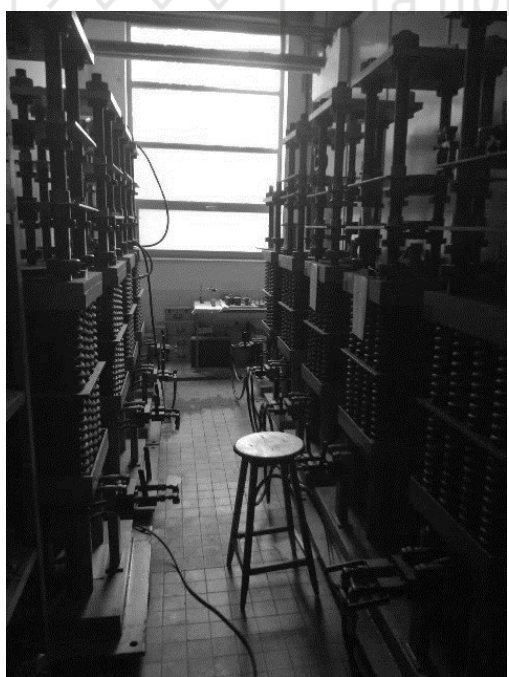

Fig. 3.4. Set of 9 spring-hydraulic creepers

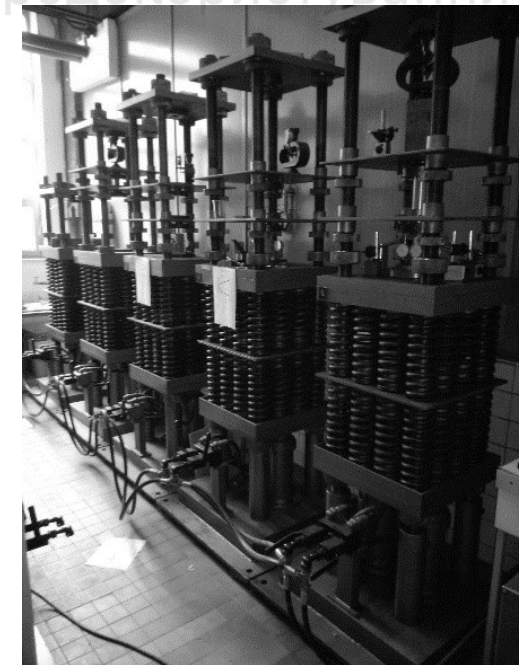

Fig. 3.5. Each creeper tests $2-3$ samples simultaneously 


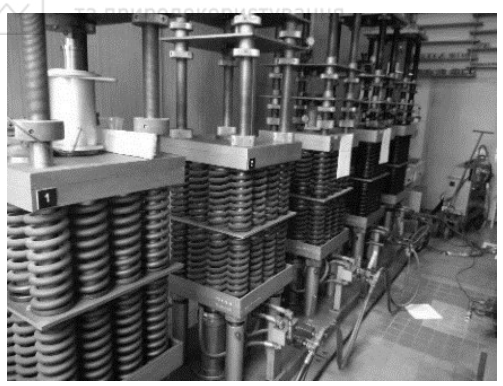

Fig. 3.6. View of a set of springhydraulic creepers. The first from the left is a triaxial tes

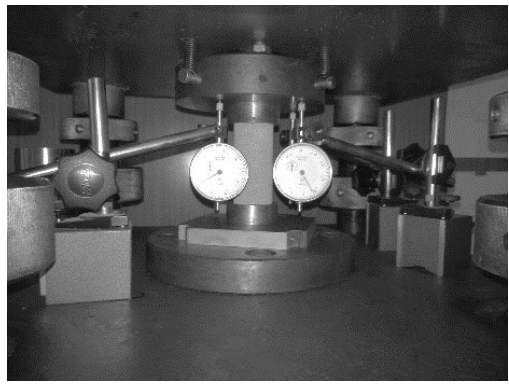

Fig. 3.7. View of the rock sample tested in the uniaxial creep

3.3. The results of research on the phenomenon of creep (based on Borecki et al., [3-6])

\subsubsection{Basic rock characteristic}

Five types of rocks from the upper-saddle layers were investigated. They were: clay, mudstone, sandstone (Jastrzębie) and conglomerate.

The cores were drilled from a depth of $-200 \mathrm{~m}$. They had a diameter of $42 \mathrm{~mm}$ and a slenderness $(h: d)$ of 2 . All tests were laboratory tests in which the principles of the recommendations of the International Society of Rock Mechanics were followed.

After cutting, the samples were ground with the following accuracy:

- deviation of parallelism of the frontal planes of the sample: $0.05 \mathrm{~mm}$,

- longitudinal axis deviation $<0.05 / 50 \mathrm{~mm}$,

- convexity of face surfaces $<0.03 \mathrm{~mm}$.

Before starting the tests, the samples were stored under normal conditions, i.e. temperature $18-24^{\circ}$, humidity $60-70 \%$, for about 6 weeks.

The basic properties of the rocks are presented in Table 3.1. Although only the behaviour of the Jastrzębie sandstone will be analysed, the table lists the constants of the remaining sedimentary rocks in order to better describe the properties of the surrounding rock mass. 
Tab. 3.1

Parameters of the tested rocks

\begin{tabular}{|c|c|c|c|c|c|c|c|}
\hline \multirow{3}{*}{$\begin{array}{l}\text { Quantity } \\
\text { Specific } \\
\text { gravity } \\
\llcorner\llcorner\llcorner\mathrm{kN} / \\
\mathrm{m}^{3}\end{array}$} & \multicolumn{6}{|c|}{ Rock type } & \multirow[b]{2}{*}{$\begin{array}{c}\text { Mudsto } \\
\text { ne }(G)\end{array}$} \\
\hline & $\begin{array}{c}\text { Claysto } \\
\text { ne (A) }\end{array}$ & $\begin{array}{c}\text { Mudsto } \\
\text { ne (B) }\end{array}$ & \multicolumn{2}{|c|}{$\begin{array}{l}\text { Jastrzębie } \\
\text { sandstone }\end{array}$} & $\begin{array}{c}\text { Conglo } \\
\text { merate } \\
\text { (E) }\end{array}$ & $\begin{array}{c}\text { Claysto } \\
\text { ne }(\mathrm{F})\end{array}$ & \\
\hline & 26.3 & 26.2 & 25.8 & 26.8 & 25.4 & 26.9 & 27.6 \\
\hline $\begin{array}{c}\text { Volumetri } \\
\text { c weight } \\
\llcorner\llcorner\llcorner\mathrm{kN} / \\
\mathrm{m}^{3}\end{array}$ & 25.8 & 26.0 & 24.4 & 25.5 & 24.5 & 25.4 & 26.0 \\
\hline $\begin{array}{c}\text { Volumetri } \\
\text { c porosity } \\
n_{o,} \% \\
\end{array}$ & 2.2 & 0.9 & 5.2 & 4.2 & 3.6 & 5.5 & 5.6 \\
\hline $\begin{array}{c}\text { Weight } \\
\text { water } \\
\text { absorbabili } \\
\text { ty } \\
n_{w}, \%\end{array}$ & 0.8 & 0.3 & 2.1 & 1.6 & | $/ 1.5$ & 2.100 & $2.1 \ominus T$ \\
\hline $\begin{array}{l}\text { Elastic } \\
\text { modulus } \\
E_{s}, \mathrm{GPa} \\
\end{array}$ & 15.5 & 37.7 & 31.3 & 30.8 & 41.8 & 17.2 & $\begin{array}{r}14.8 \\
-148\end{array}$ \\
\hline $\begin{array}{l}\text { Deformati } \\
\text { on } \\
\text { modulus } \\
E_{o}, \mathrm{GPa}\end{array}$ & 16.8 & 41.1 & 32.3 & 30.0 & 34.5 & 17.6 & 16.1 \\
\hline $\begin{array}{c}\text { Poisson's } \\
\text { ratio } \\
L,-\end{array}$ & 0.17 & 0.23 & 0.16 & 0.17 & 0.15 & 0.17 & 0.17 \\
\hline $\begin{array}{c}\text { Uniaxial } \\
\text { compressi } \\
\text { ve strength } \\
R_{c}(\llcorner C) \\
\mathrm{MPa}\end{array}$ & 90.6 & 106.8 & 83.5 & 111.2 & 83.4 & 76.6 & 79.6 \\
\hline $\begin{array}{c}\text { Uniaxial } \\
\text { tensile } \\
\text { strength } \\
R_{r}\left(\left\llcorner_{T}\right),\right. \\
\mathrm{MPa}\end{array}$ & 10.0 & 10.0 & 6.0 & 10.3 & 7.2 & 7.7 & 9.2 \\
\hline
\end{tabular}

3.3.2. Selected results of rheological tests of the Jastrzębie sandstone in the context of its deformability

Selected results of the Jastrzębie sandstone creep rheological tests, and more specifically the elasticity modulus (deformability 
coefficient) $E^{3}$ for various creep models are showed in Table 3.2. The creep tests lasted from 204 to 1302 hours, depending on the value of $\square_{0}$ and the creep limits or failure of the rock samples.

Tab. 3.2

Values of the modulus of the elasticity modulus (deformability coefficient) $E$ for different creep models and for different stress values $\mid=1_{0}=$ const. (based Borecki et al., [2-6]).

\begin{tabular}{|c|c|c|c|c|c|c|c|}
\hline \multirow{9}{*}{ 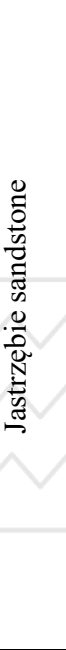 } & \multirow{2}{*}{$\begin{array}{c}\text { Load level } \\
1 \\
\end{array}$} & \multicolumn{2}{|c|}{ Zener model } & \multicolumn{2}{|c|}{ Burgers model } & \multirow{2}{*}{$\begin{array}{c}\begin{array}{c}\text { Abel } \\
\text { model }\end{array} \\
6\end{array}$} & \multirow{2}{*}{$\begin{array}{c}\text { Robotnov } \\
\text { model }\end{array}$} \\
\hline & & 2 & 3 & 4 & 5 & & \\
\hline & $\sigma_{0} \mathrm{MPa}$ & $\begin{array}{c}E_{1} \\
\mathrm{GPa}\end{array}$ & $\begin{array}{c}E_{2} \\
\mathrm{GPa}\end{array}$ & $E_{1} \mathrm{GPa}$ & $\begin{array}{c}E_{2} \\
\mathrm{GPa}\end{array}$ & $E \mathrm{GPa}$ & $E_{1} \mathrm{GPa}$ \\
\hline & $\begin{array}{c}41.7 \\
\left(0.50 \sigma_{C}\right) \\
\end{array}$ & 17.6 & 968 & 16.7 & 1476 & 17.6 & 17.6 \\
\hline & $\begin{array}{c}50.1 \\
\left(0.60 \sigma_{C}\right)\end{array}$ & 20.3 & 674 & 20.3 & 1200 & 20.4 & 20.5 \\
\hline & $\begin{array}{c}58.4 \\
\left(0.70 \sigma_{C}\right)\end{array}$ & 22.8 & 601 & 23.1 & 760 & 23.2 & 323.1 \\
\hline & $\begin{array}{c}62.6 \\
\left(0.75 \sigma_{C}\right)\end{array}$ & 20.9 & 512 & 21.0 & 656 & 21.3 & 21.2 \\
\hline & $\begin{array}{c}66.7 \\
\left(0.80 \perp_{C}\right)\end{array}$ & 18.1 & 112 & 18.5 & 422 & 18.3 & 18.8 \\
\hline & $\begin{array}{c}75.1 \\
\left(0.90 \sigma_{C}\right)\end{array}$ & 23.8 & 489 & 25.5 & 861 & 24.2 & 24.2 \\
\hline
\end{tabular}

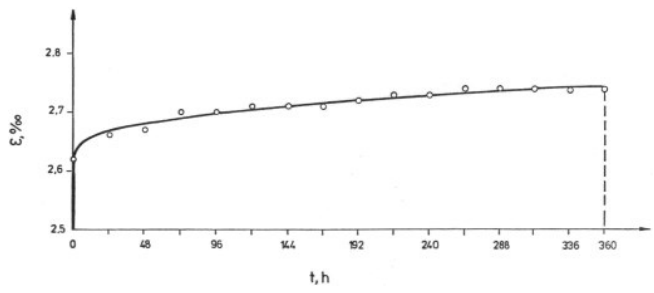

Fig. 3.8. Creep characteristic of Jastrzębie sandstone: $\sigma_{0}=0.6 \sigma_{C}$. Abel creep function; $\sigma_{0}=50.1 \mathrm{MPa}, E=19.1 \mathrm{GPa}, \delta=0.0020 \cdot h^{\cdot \alpha-1}, \delta=0.0020[2-6]$

${ }^{3}$ Being aware of the differences between the modulus of elasticity and the deformation coefficient, it was assumed that in accordance with the results of short-term compression tests, these coefficients can be identified. 


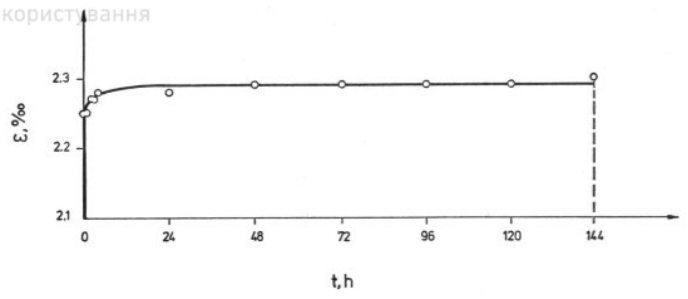

Fig. 3.9. Creep characteristic of Jastrzebie sandstone: $\sigma=0.5 \cdot \sigma_{c}$. Zener creep function; $\sigma_{0}=41.7 \mathrm{MPa}, E_{1}=18.6 \mathrm{GPa}, E_{2}=9.6 \mathrm{GPa} \lambda_{2}=3266 \mathrm{Pah}[2-6]$.

From the point of view of the analysis, in this chapter we are interested in the analysis of the $E$ values in columns 2,4 and 6 . The test results show that the differences in the $E$ values for the same stress values $\sigma_{0}$ do not exceed 1.0MPa.

The second, more important observation is that for different values of $\sigma_{0}$ the limit values of $E$ at time $t$ are different. They vary depending on the creep model from 16.7 to $25.5 \mathrm{GPa}$. This represents an increase of approximately 52\%. Examples of creep curves for various models are shown in Figs 3.8-3.13. Most of the curves show that the creep has stabilized in shape.

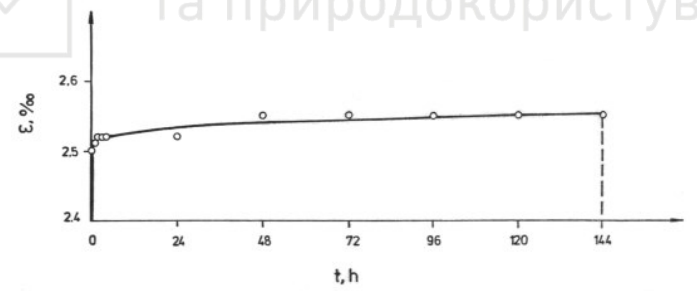

Fig. 3.10. Creep characteristic of Jastrzębie sandstone: $\sigma_{0}=0.5 \cdot \sigma_{C}$. Rabotnov creep function; $\sigma_{0}=41.7 \mathrm{MPa}, E=16.7 \mathrm{GPa}, \chi=0.0082 \cdot h^{\cdot \alpha-1}, \beta=0.1099 \cdot h^{\cdot \alpha-1}[2-6]$

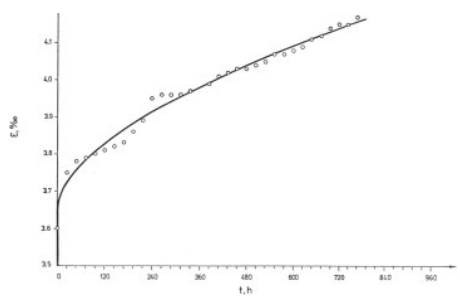

Fig. 3.11. Creep characteristic of Jastrzębie sandstone: $\sigma_{0}=0.8 \cdot \sigma_{C}$. Abel creep function; $\sigma_{0}=66.7 \mathrm{MPa}, E=18.3 \mathrm{GPa}, \sigma=0.0018 \cdot h^{\cdot \alpha-1}, \alpha=0.433 \cdot h^{\cdot \alpha-1}[2-6]$ 


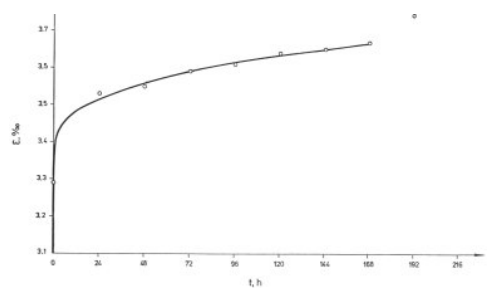

Fig. 3.12. Creep characteristic of Jastrzębie sandstone: $\sigma_{0}=0.9{ }^{\circ} \sigma_{C}$. Rabotnov creep function; $\sigma=75.1 \mathrm{MPa}, E=22.8 \mathrm{GPa}, \chi=0.0404^{\cdot} h^{\alpha-1}, \beta=0.1189 \cdot h^{\alpha-1}[2-6]$

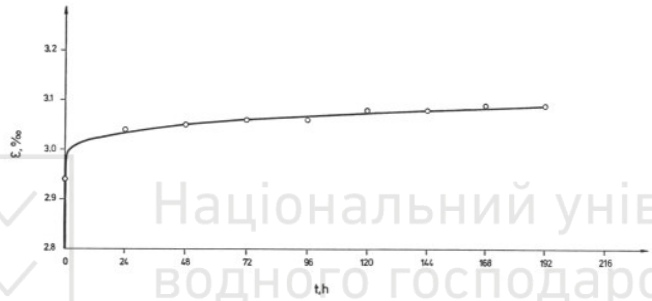

Fig. 3.13. Creep characteristic of Jastrzębie sandstone: $\sigma_{0}=0.9 \cdot \sigma_{C}$. Rabotnov creep function; $\sigma_{0}=75.1 \mathrm{MPa}, E=25.5 \mathrm{GPa}, d=0.0219 \cdot h^{\cdot \alpha-1}, \alpha=0.2632 \cdot h^{\cdot \alpha-1}[2-6]$

\section{Deformation properties of Jastrzębie sandstone under uniaxial short-term compression}

Laboratory uniaxial compression tests were carried out in the servo-operated test laboratory. The tests were conducted in accordance with the recommendations of the ISRM. These studies have already been described in other publications (see Tomiczek, [24-27]). The diameter of the cylindrical rock samples $d$ was equal to $42 \mathrm{~mm}$, and the slenderness $d: h=2$.

Tab. 4.1

Research results on deformation properties of Jastrzębie sandstone under the shortterm uniaxial compression conditions

\begin{tabular}{|c|c|c|c|c|c|}
\hline \multirow{2}{*}{\multicolumn{3}{|c|}{ Rock type and sample symbol }} & \multicolumn{3}{|c|}{ Jastrzębie sandstone } \\
\hline & & & $220 \mathrm{~F} 1$ & $220 \mathrm{~F} 2$ & $220 \mathrm{~F} 3$ \\
\hline \multirow{2}{*}{ Dimensions } & \multicolumn{2}{|c|}{ diameter $d, \mathrm{~cm}$} & 4.13 & 4.14 & 4.16 \\
\hline & \multicolumn{2}{|c|}{ height $h, \mathrm{~cm}$} & 8.22 & 8.22 & 8.21 \\
\hline \multicolumn{2}{|c|}{ Slenderness } & $h: d$ & 1.99 & 1.99 & 1.97 \\
\hline \multicolumn{2}{|c|}{ Cross-sectional area } & $S, \mathrm{~cm}^{2}$ & 13.40 & 13.46 & 13.59 \\
\hline
\end{tabular}




\begin{tabular}{c|c|c|c|c}
\hline Short term uniaxial compression strength & $\begin{array}{c}\sigma_{C} \\
\mathrm{MPa}\end{array}$ & 136.45 & 102.25 & 87.59 \\
\hline $\begin{array}{c}\text { Secant coefficient of axial deformability } \\
\text { at the stress level } \sigma_{z}=0.5 \sigma_{C}\end{array}$ & $\begin{array}{c}E_{s 50} \\
\mathrm{GPa}\end{array}$ & 29.02 & 23.16 & 19.79 \\
\hline $\begin{array}{c}\text { Mean axial deformation coefficient at } \\
\text { the stress level } \sigma_{z}=0.5 \sigma_{C}\end{array}$ & $\begin{array}{c}E_{m 50} \\
\mathrm{GPa}\end{array}$ & 29.51 & 22.11 & 20.87 \\
\hline $\begin{array}{c}\text { Linear axial deformation coefficient } \\
\text { (equal to } E \text { ) }\end{array}$ & $\begin{array}{c}E_{l}\left(E_{t 50}\right) \\
\mathrm{GPa}\end{array}$ & 30.34 & 28.60 & 23.23 \\
\hline Poisson's ratio & $v$ & 0.214 & 0.129 & 0.151 \\
\hline
\end{tabular}

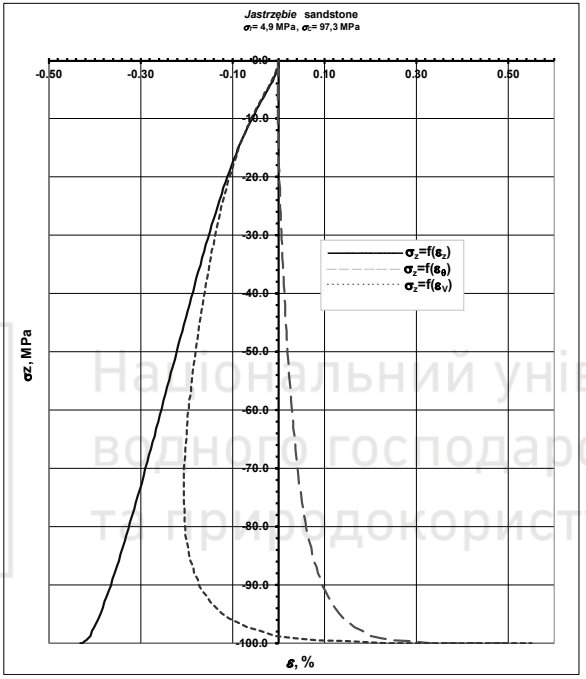

Fig. 4.1. Typical: normal stress $\sigma_{z}$ - axial $\varepsilon z$, lateral $\varepsilon \theta$ and volumetric strain $\varepsilon v$ characteristics of the Jastrzębie sandstone in the uniaxial (short-term) compression test. Compressive stresses and strains are assumed to be negative in this figure

Tab. 4.2

Deformational coefficients (modulus of elasticity) in short-term and creep tests

\begin{tabular}{r|r||r|r|r|r|r}
\hline$\sigma_{C} \mathrm{MPa}$ & \multicolumn{1}{c||}{$E_{s} \mathrm{GPa}$} & $\sigma_{0} \mathrm{MPa}$ & $E_{m Z} \mathrm{GPa}$ & $E_{m B} \mathrm{GPa}$ & $E_{m A} \mathrm{GPa}$ & $E_{m R} \mathrm{GPa}$ \\
\hline 83.5 & 31.3 & 41.7 & 17.6 & 16.7 & 17.6 & 17.6 \\
\hline 87.6 & 23.2 & 50.1 & 20.3 & 20.3 & 20.4 & 20.5 \\
\hline 102.3 & 28.6 & 58.4 & 22.8 & 23.1 & 23.2 & 23.1 \\
\hline 111.2 & 30.8 & 62.6 & 20.9 & 21.0 & 21.3 & 21.2 \\
\hline 136.5 & 30.3 & 66.7 & 18.1 & 18.5 & 18.3 & 18.8 \\
\hline \multicolumn{1}{r||}{} & 75.1 & 23.8 & 25.5 & 24.2 & 24.2 \\
\hline
\end{tabular}

where $\sigma_{C}$ - uniaxial (short-term) compressive strength, $E_{s}$ - modulus of elasticity determined on the basis of uniaxial (short-term) compression tests, $\sigma_{0}$ - value (constant) of stress in creep tests, $E_{m z}, E_{m B}, E_{m A}$ and $E_{m R}$ - modulus of elasticity of Zener, Burgers, Abel and Rabotnov models, in creep tests 
Jastrzębie sandstone samples have a mid-range value of uniaxial compression strength $\sigma_{C}$. This strength of the Jastrzębie sandstone is approximately $109 \mathrm{MPa}$.

The average values of the deformation coefficients (modulus of elasticity) $E_{t 50}$ and $E_{m 50}$ of the Jastrzębie sandstone are approximately $27.4 \mathrm{GPa}$ and $24.0 \mathrm{GPa}$, respectively.

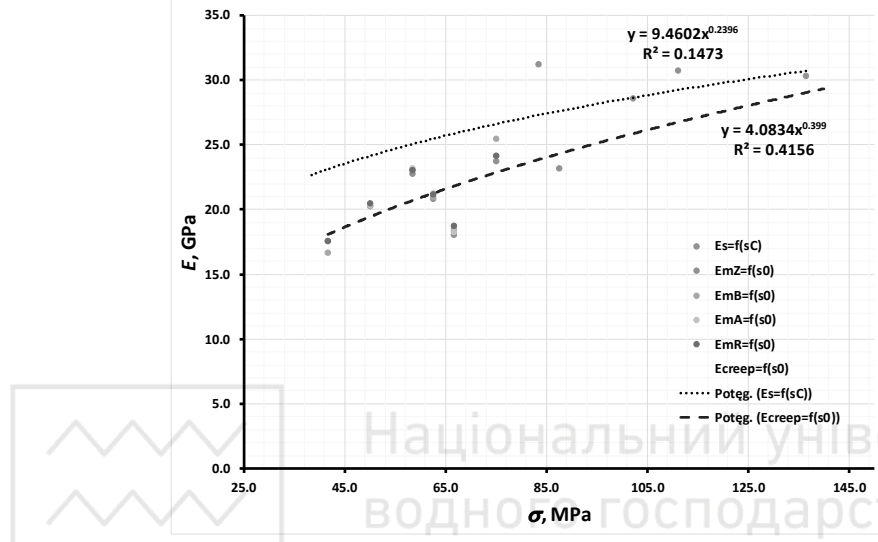

Fig. 4.2. The relationship between the stress $\sigma$ and the deformation coefficient (modulus of elasticity) $E$. $\sigma_{C}$ - under (short-term) uniaxial compressive strength tests, $m Z, m B, m A, m R$ - of Zener, Burgers, Abel and Rabotnov models, creep - for all creep models, $\sigma_{0}-$ stress, $\sigma_{0}=$ const. in creep, Poteg. - approximating power function

Comparison of the value of the elastic modulus (deformation coefficient) $E$ in tab. 4.2 and in Fig. 4.2 means that the values of $E$ strongly depend on the value of the stress $\sigma_{0}$ (or $\sigma_{C}$ ). The values of $E$, generally increase as $\sigma_{0}$ increases. From the value of about $16.7 \mathrm{G} \mathrm{Pa}$, at $\sigma_{0}=41.7 \mathrm{MPa}$ for the Burgers model to about $25.5 \mathrm{G} \mathrm{Pa}$, at $\sigma_{0}=75.1 \mathrm{MPa}$, also for the Burgers model.

In addition, as shown by the results of short-term uniaxial compression tests, the $E$ value in these tests is definitely higher than in the long-term creep tests. These differences reach $5 \mathrm{G} \mathrm{Pa}$, with values of $23.2 \mathrm{G} \mathrm{Pa}$, which is from 16 to $22 \%$.

Figure 4.3. shows the relationship between the primary creep time (stage I, transient) $t$ and the modulus of elasticity $E$, taking into account the uniaxial compression tests. The presented data show that the important factor influencing the value of $E$, regardless of the 
value of the compressive stress $\sigma$, is the time $t$, especially in the Ist stage of creep, when there is an intensive closure of the micro-voids. The differences in the values of $E$, resulting from the load time, are large, reaching $8 \mathrm{GPa}$. The $E$ values for sandstone under short-term stress (uniaxial compression tests) are definitely higher.

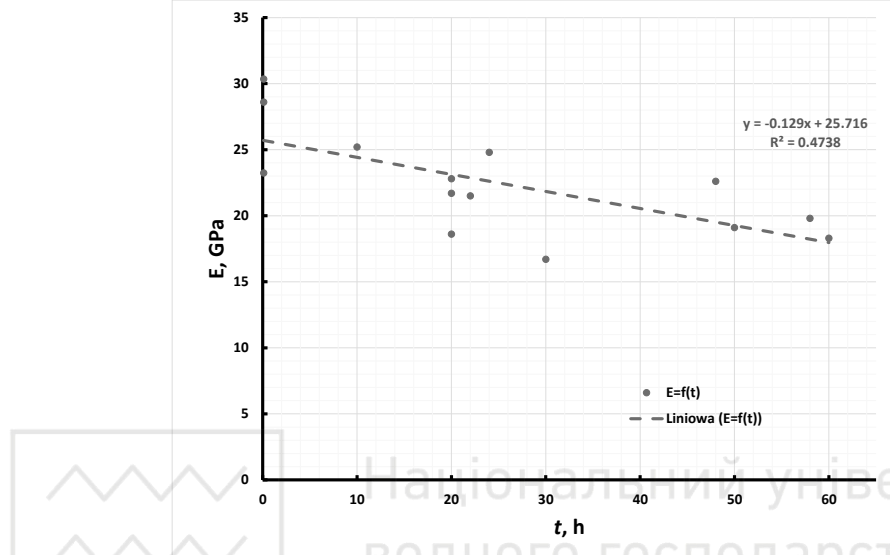

Fig. 4.3. The relationship between the primary creep time (stage I, transient) $t$ and the modulus of elasticity $E$, taking into account the uniaxial (short-term) compression tests; Liniowa - approximating linear function

\section{Summary and final remarks}

The chapter highlights the neglected in recent years, effect of the time factor influence on the deformation properties of rocks. Selected results of research conducted by professors Borecki and Kwaśniewski at the Department of Geomechanics and Underground Construction (now) are presented. The well-known Jastrzębie sandstone was selected, which has been the subject of comprehensive own research in recent years. This medium-fine sandstone is quasiisotropic and qasi-homogeneous.

Particular attention was paid to the variability of the value of the modulus of elasticity (deformation coefficient) $E$. As shown, the time $t$ and the value of the (compressive) stress in the time $\sigma_{0}=$ const. (or $\sigma)$ have a strong influence on deformation properties:

1. Values of $E$, generally increase with increasing (long-term) stress $\sigma_{0}$. From the value of about $16.7 \mathrm{GPa}$ for $\sigma_{0}=41.7 \mathrm{MPa}$ to about $25.5 \mathrm{GPa}$ at $\sigma_{0}=75.1 \mathrm{MPa}$. 
2. As shown by the results of short-term uniaxial compression tests, the $E$ value in these tests is definitely higher than in the longterm creep tests. These differences reach $5 \mathrm{GPa}$, with values of 23.2GPa, which is from 16 to $22 \%$.

3. Presented data show that the important factor influencing the value of $E$, regardless of the value of the compressive stress $\sigma$, is the time $t$, especially in the Ist stage of creep, when there is an intensive closure of the micro-voids. The differences in the values of $E$, resulting from the load time, are large, reaching $8 \mathrm{GPa}$. The $E$ values for sandstone under short-term stress (uniaxial compression tests) are definitely higher.

Rocks, including those in the vicinity of underground headings, tunnels and chambers, remain under stress for long time. Rock properties are determined as standard short-time tests. It is widely recognized that there is a need for studies on rocks that creep strongly, such, as rock salt.

However, as the research shows, the variability of the properties of typical Carboniferous rocks over time is an important indicator of describing the state of the rock mass. This is the reason why this research is needed.

Sources (selected)

1. Borecki M.: Badania nad określeniem wskaźnika reologicznego skłonności węgla do tąpan. Research on the determination of the rheological coefficient of coal rockbursts. Zeszyty Naukowe Politechniki Śląskiej nr 571, s. Górnictwo z. 88, 3-15, 1979

2. Borecki M., Chudek M. i Oleksy S.: Problemy wpływu anizotropii masywu skalnego na stan naprężeniowo-deformacyjny wokół wyrobisk górniczych. Problems of the influence of anisotropy of a rock mass on the stress-deformation state around underground excavations. ZN Politechniki Śląskiej, $\mathrm{nr} 555$, s. Górnictwo, z. 85, 15-28, 1977

3. Borecki M., Oleksy S. i Pacha J.: Aproksymacja krzywych pełzania skał jako ośrodka dziedzicznego o modelu całkowym. Approximation of creep curves of rocks as a inheritance medium with an integral model. Prace Naukowe Instytutu Geotechniki Politechniki Wrocławskiej, nr 26, s.Konferencje, nr 10, 175-185, 1978

4. Borecki M., Kwaśniewski M. i Oleksy S.: Ciśnienie deformacyjne górotworu jako ośrodka reologicznego działającego na obudowę wyrobiska korytarzowego. The deformation stress of the rock mass with rheological properties acting on the heading support. ZN Politechniki Śląskiej, nr 595, s.Górnictwo, z.96, 23-34, 1979

5. Borecki M., Kwaśniewski M., Oleksy S., Ordysiński Z., Wojciechowski S. i Żyliński R.: Podstawy teoretyczne i metodyczne badania własności reologicznych 
skał. Fundamentals of theoretical and methodological studies on the rheological properties of rocks. Opracowanie Instytutu Projektowania, Budowy Kopaln i Ochrony Powierzchni Politechniki Śląskiej, 125/3.1.3.1, Gliwice 1976

6. Borecki M., Kwaśniewski M., Oleksy S. i Pacha J.: Badania nad pełzaniem skał karbońskich warstw siodłowych z kopalni Jastrzębie. Research on rock creep of Carboniferous saddle layers from the Jastrzębie coal mine. Opracowanie Instytutu Projektowania, Budowy Kopalń i Ochrony Powierzchni Politechniki Śląskiej, 115/3.3, Gliwice 1978

7. Chudek M. Mechanika górotworu. Rock mechanics. Skrypt centralny wyższych studiów technicznych dla pracujących, nr 956/61, Gliwice 1981

8. Glamheden R. and Hökmark H.: Creep in jointed rock masses. Svensk Kärnbränslehantering AB, Swedish Nuclear Fuel and Waste Management, 00R-0694CM, 2010-2011

9. Kisiel I.: Reologia skał. Podstawy naukowe. Rock rheology. Scientific foundations. Polska Akademia Nauk, Wydawnictwo PAN, Warszawa 1973

10. Kisiel I.: Reologia w budownictwie. Rheology in civil engineering, Wyd. Arkady, Warszawa 1967

11. Kłeczek Z.: Doświadczalne kryterium doboru modelu reologicznego dla skał. Experimental criterion for selecting a rheological model of rocks. Prace Komisji Nauk Technicznych PAN, Górnictwo 5, PWN, Kraków 1968

12. Kłeczek Z.: Geomechanika górnicza. Mining geomechanics. Śląskie Wydawnictwo Techniczne. Katowice 1994

13. Kwaśniewski M.*: Funkcje pełzania skał. Rock creep functions. Zeszyty Problemowe Górnictwa, t.15, z.2, s. 3-50, 1977

14. Kwaśniewski M.: Granica stosowalności modelu lepkosprężystości liniowej do opisu reologicznych własności skał. The limit of applicability of the linear viscoelasticity model for the description of rheological properties of rocks. Prace Naukowe Instytutu Geotechniki Politechniki Wrocławskiej nr 31, Konferencje nr 12, 41-49, 1980

15. Kwaśniewski M.: Wpływ stanu naprężenia, temperatury i prędkości odkształcania na mechaniczne własności skał. Influence of the stress state, temperature and strain rate on the mechanical properties of rocks. Archiwum Górnictwa, t. 31, z. 2, 383-415, 1986

16. Kwaśniewski M. and Nguyen V.H.: Experimental studies on anisotropy of time-dependent behaviour of bedded rocks. In Proceedings of the International Symposium on Engineering in Complex Rock Formations, Beijing 1986, pp. 325 337. Pergamon Books Ltd. and Science Press, Beijing 1986

17. Mitzel A.: Reologia betonu. Concrete rheology. Arkady, Warszawa 1972

18. Rabotnov Yu. N.: Creep Problems in Structural Members. North-Holland Publishing Company, Amsterdam - London, 1969

19. Reiner M.: Twelve lectures on theoretical rheology. North Holland Publishing Co., Amsterdam 1949

20. Reiner M.: Rheologie theorique. Dunod, Paris 1955

21. Sałustowicz A.: Mechanika Górotworu. Rock mechanics. Wydawnictwo Górniczo-Hutnicze, Katowice 1955 
22. Salustowicz A.: Górotwór jako ośrodek sprężysto-lepki. Rock mass as an elastic-viscous medium. Archiwum Górnictwa, t.III, z.2, PWN, Warszawa 1958

23. Singh D.P.: A study of creep of rocks. International Journal of Rock Mechanics and Mining Sciences \& Geomechanics Abstracts, Volume 12, Issue 9, pp. 271-276, September 1975

24. Tomiczek K.: Badanie właściwości procesu odkształcania się i kruchego pękania skał przy ściskaniu oraz przy rozciąganiu w oparciu o wykorzystanie metody elementów odrębnych. Research on the properties of the process of deformation and brittle fracture of rocks under compression and tension based on the the Distinct Element Method. Prace Katedry Geomechaniki, Budownictwa Podziemnego i Ochrony Powierzchni Politechniki Śląskiej, BW-487/RG-4/99, Gliwice 1999

25. Tomiczek K.: Symulacja próby jednoosiowego ściskania próbki ziarnistego materiału skalnego. Simulation of uniaxial compression test of a granular rock sample. Prace Naukowe Instytutu Geotechniki i Hydrotechniki Politechniki Wrocławskiej; nr 73 Seria: Konferencje; nr 40 1230-3100, 2002

26. Tomiczek K.: O własnościach wytrzymałościowych i odkształceniowych pewnego piaskowca $\mathrm{w}$ warunkach trójpunktowego zginania $\mathrm{w}$ kontekście jego zachowania się przy rozciąganiu i ściskaniu. Strength and deformation properties of certain sandstone under three-point bending conditions in the context of its tensile and compression behavior. "Górnictwo Zrównoważonego Rozwoju 2018" konferencja naukowa, Gliwice, 28. listopada 2018

27. Tomiczek K.: A note on the strength and deformation properties of a some sandstone under three-point bending in the context of tension and compression behaviour. Mining of Sustainable Development IOP Conf. Series: Earth and Environmental Science 261, 012055IOP, Publishing doi:10.1088/17551315/261/1/012055, 2019

(*) - Marek Kwaśniewski (1947-2014), PhD, DSc, Professor at Silesian University of Technology, the head of the Rock Mechanics Laboratory (1975-2014, SUoT), Secretary-General of the International Bureau of Strata Mechanics (19731988), President of the Polish National Group of the International Society of Rock Mechanics (2007-2014), Editor-in-Chief of the Geomechanics Research Series from CRC Press/Balkema (since 1987), member of the editorial boards of Archives of Mining Sciences (since 1999) and Rock Mechanics \& Rock Engineering (since 2009), Author of more than two hundred research articles and several monographs. Professor Kwaśnieski's special interests were: the influence of anisotropy, triaxial studies and research on the phenomenon of dilatancy as a harbinger of rock failure. 